\title{
ANALISIS KORELASI FAKTOR PENERAPAN K3 TERHADAP KINERJA WAKTU PADA PROYEK KONSTRUKSI
}

\author{
Michael Marlee ${ }^{1}$ dan Hendrik Sulistio ${ }^{2}$ \\ ${ }^{1}$ Program Studi Sarjana Teknik Sipil, Universitas Tarumanagara, Jl. Letjen S.Parman No.1 Jakarta \\ Email: michaelmarlee2@gmail.com \\ ${ }^{2}$ Program Studi Doktor Teknik Sipil, Universitas Tarumanagara, Jl. Letjen S.Parman No.1 Jakarta \\ Email: hendriks@ft.untar.ac.id
}

\begin{abstract}
ABSTRAK
Pada pelaksanaan proyek konstruksi, beberapa hal yang tidak diharapkan dan tidak diantisipasi dapat terjadi dan mempengaruhi waktu penyelesaian yang dibutuhkan. Keselamatan dan kesehatan kerja yang tidak diperhatikan dengan baik dalam suatu proyek konstruksi dapat menyebabkan terjadinya kecelakaan kerja. Keselamatan dan kesehatan kerja merupakan hal yang penting bagi perusahaan, karena dampak dari kecelakaan kerja sangatlah merugikan. Pekerja yang mengalami kecelakaan kerja akan mengganggu waktu penyelesaian proyek secara keseluruhan. Oleh karena itu, perlu dilakukan analisis untuk mengetahui penerapan keselamatan dan kesehatan kerja yang berhubungan signifikan terhadap kinerja waktu. Analisis ini dilakukan dengan menggunakan metode Pearson Product Moment untuk melihat hubungan antar variabel yang ditunjukan dengan nilai $\mathrm{r}$. Data diambil dengan menyebarkan kuisioner terhadap pekerja pada proyek konstruksi. Data yang didapat kemudian diolah dengan bantuan program pengolah statistik SPSS. Hasil dari analisis menunjukkan dari 21 variabel penerapan keselamatan dan kesehatan kerja, 16 variabel berkorelasi signifikan terhadap kinerja waktu. Penerapan keselamatan dan kesehatan kerja yang berkorelasi paling tinggi terhadap kinerja waktu yaitu mengatur penempatan prasarana kerja, peralatan, dan bahan.
\end{abstract}

Kata kunci: Keselamatan dan kesehatan kerja, kinerja waktu, pearson product moment

\section{PENDAHULUAN}

\section{Latar belakang}

Pekerjaan Konstruksi adalah keseluruhan atau sebagian rangkaian kegiatan perencanaan dan pelaksanaan beserta pengawasan untuk mewujudkan suatu bangunan dalam jangka waktu tertentu. Jasa konstruksi adalah sebuah sektor yang memegang peran penting dalam pembangunan Indonesia. Proyek mempunyai sifat unik dimana tidak ada proyek yang identik, yang ada yaitu proyek sejenis. Proyek konstruksi tidak pernah terjadi rangkaian kegiatan yang sama persis satu sama lain, bersifat sementara dan selalu melibatkan grup pekerja yang berbeda-beda.

Menurut peraturan menteri tenaga kerja nomor : PER.05/MEN/1996, tujuan dan sasaran sistem manajemen keselamatan dan kesehatan kerja (SMK3) adalah menciptakan suatu sistem keselamatan dan kesehatan kerja di tempat kerja dengan melibatkan unsur manajemen, tenaga kerja dan lingkungan kerja yang terintegrasi dalam rangka mencegah dan mengurangi kecelakaan dan penyakit akibat kerja serta terciptanya tempat kerja yang aman, efisien dan produktif.

Proyek konstruksi di Jakarta sering mengalami keterlambatan kerja. Ini menunjukan bahwa kinerja waktu proyek yang kurang baik. Kinerja waktu adalah membandingkan antara waktu yang telah direncanakan dan disepakati antara owner dengan kontraktor dengan waktu aktual penyelesaian proyek (actual work), bila presentasenya makin kecil maka kinerjanya makin baik. Keterlambatan yang terjadi dalam suatu proyek dapat disebabkan oleh banyak faktor dimana salah satunya yaitu penerapan manajemen K3 yang kurang baik.

Penerapan manajemen K3 di Jakarta tergolong kurang baik.peraturan-peraturan yang dipakai sebenarnya sudah cukup baik seperti peraturan menteri tenaga kerja nomor : PER.05/MEN/1996 dan OHSAS (Occupational Health and Safety Assesment Series). Namun tingkat penerapan proyek dalam mematuhi peraturan-peraturan tersebut masih kurang. Kurang baiknya penerapan sistem manajemen keselamatan dan kesehatan kerja (SMK3) menyebabkan semakin tingginya kemungkinan terjadinya kecelakaan kerja.

Terjadinya kecelakaan kerja pada suatu proyek dapat mempengaruhi kinerja proyek secara keseluruhan baik dalam segi fisik, material, biaya dan juga waktu. Kerugian-kerugian tersebut antara lain dapat timbulnya kerugian jiwa, 
pengeluaran biaya akibat kecelakaan, serta tertundanya pelaksanaan pekerjaan yang berkemungkinan mempengaruhi waktu pekerjaan proyek secara keseluruhan. Selain kecelakaan kerja, penerapan sistem manajemen keselamatan dan kesehatan kerja (SMK3) yang kurang baik juga dapat memperlambat kinerja waktu proyek seperti sampah yang berserakan dapat mengganggu pekerjaan tukang yang kemudian akan berpengaruh terhadap durasi proyek. Oleh karena itu, Analisis korelasi penerapan keselamatan dan kesehatan kerja pada proyek konstruksi terhadap kinerja waktu proyek dilakukan.

\section{Rumusan masalah}

1. Bagaimana penerapan manajemen K3 pada proyek konstruksi Indonesia 1 dan The Spring Residence?

2. Bagaimana korelasi antara penerapan keselamatan dan kesehatan kerja terhadap kinerja waktu pada proyek konstruksi Indonesia 1 dan The Spring Residence?

3. Bagaimana korelasi antara kecelakaan kerja terhadap kinerja waktu pada proyek konstruksi Indonesia 1 dan The Spring Residence?

4. Bagaimana penanggulangan variabel penerapan keselamatan dan kesehatan kerja yang berkorelasi paling kuat terhadap kinerja waktu proyek konstruksi Indonesia 1 dan The Spring Residence?

\section{Tujuan penelitian}

1 Mengetahui tingkat penerapan keselamatan dan kesehatan (K3) proyek konstruksi Indonesia 1 dan The Spring Residence.

2 Mengetahui korelasi antara penerapan keselamatan dan kesehatan kerja yang dominan terhadap kinerja waktu proyek konstruksi gedung bertingkat Indonesia 1 dan The Spring Residence.

3 Mengetahui korelasi antara tingkat kecelakaan kerja terhadap kinerja waktu proyek konstruksi gedung bertingkat Indonesia 1 dan The Spring Residence.

4 Mendapatkan solusi terhadap penanggulangan variabel penerapan keselamatan dan kesehatan kerja yang berkorelasi paling kuat terhadap kinerja waktu pada proyek konstruksi gedung bertingkat Indonesia 1 dan The Spring Residence.

\section{Batasan masalah}

1. Penelitian dibatasi pada proyek konstruksi gedung bertingkat Indonesia 1 dan The Spring Residence.

2. Penelitian ini dilakukan melalui survey lapangan yaitu dengan wawancara terstruktur (Kuesioner) yang telah dibuat dan disiapkan untuk mendapat korelasi K3 dan kecelakaan kerja terhadap kinerja waktu pada proyek konstruksi.

\section{TINJAUAN PUSTAKA}

\section{Keselamatan dan kesehatan kerja}

Keselamatan dan kesehatan kerja merupakan salah satu aspek perlindungan tenaga kerja melalui penerapan teknologi pengendalian segala aspek yang berpotensi membahayakan para pekerja. Keselamatan dan kesehatan kerja diharapkan dapat menciptakan kenyamanan kerja dan keselamatan yang tinggi (Sholihah dan Kuncoro; 2014).

Keselamatan dan kesehatan kerja merupakan hal yang penting bagi perusahaan, karena dampaknya tidak hanya merugikan karyawan, tetapi juga perusahaan baik secara langsung maupun tidak langsung. Perusahaan yang baik adalah perusahaan yang benar-benar menjaga keselamatan dan kesehatan karyawannya dengan membuat aturan tentang keselamatan dan kesehatan kerja yang dilaksanakan oleh seluruh karyawan dan pimpinan perusahaan. Keselamatan dan kesehatan kerja menjadi bagian penting dalam mengelola, mengatasi dan mengendalikan bahaya yang dapat terjadi sehingga dapat menimbulkan hal-hal yang tidak diinginkan (Somad, 2013).

\section{Manajemen keselamatan dan kesehatan kerja}

Sistem manajemen keselamatan dan kesehatan kerja yang selanjutnya disebut sistem manajemen K3 dalam peraturan menteri tenaga kerja nomor : PER.05/MEN/1996 adalah bagian dari sistem manajemen secara keseluruhan yang meliputi struktur organisasi, perencanaan, tanggung jawab, pelaksanaan, penerapan, pencapaian, pengkajian dan pemeliharaaan kebijakan keselamatan dan kesehatan kerja dalam rangka pengendalian resiko yang berkaitan dengan kegiatan kerja guna terciptanya tempat kerja yang aman, efesien dan produktif. Menurut peraturan menteri tenaga kerja nomor : PER.05/MEN/1996, tujuan dan sasaran sistem manajemen keselamatan dan kesehatan kerja (SMK3) adalah menciptakan suatu sistem keselamatan dan kesehatan kerja di tempat kerja dengan melibatkan unsur 
manajemen, tenaga kerja dan lingkungan kerja yang terintegrasi dalam rangka mencegah dan mengurangi kecelakaan dan penyakit akibat kerja serta terciptanya tempat kerja yang aman, efisien dan produktif.

Peraturan menteri tenaga kerja nomor : PER.05/MEN/1996 mewajibkan setiap perusahaan yang mempekerjakan tenaga kerja sebanyak seratus orang atau lebih dan atau mengandung potensi bahaya yang ditimbulkan oleh karakteristik proses atau bahan produksi yang dapat mengakibatkan kecelakaan kerja seperti peledakan, kebakaran, pencemaran dan penyakit akibat kerja wajib menerapkan sistem manajemen K3. Sistem manajemen K3 tersebut wajib dilaksanakan oleh pengurus, pengusaha dan seluruh tenaga kerja sebagai satu kesatuan.

\section{Kecelakaan kerja}

Kecelakaan kerja sebagaimana didefinisikan menurut Heinrich (1980) sebagai suatu kejadian yang tidak terencana dan tidak terkontrol yang merupakan aksi atau reaksi dari suatu objek, substansi, manusia, atau radiasi yang memungkinkan atau dapat menyebabkan injury. Selain itu Frank E. Bird dan George L. Germain mendefinisikan kecelakaan sebagai suatu kejadian yang tidak diinginkan yang menimbulkan kerugian pada manusia, kerusakan property, ataupun kerugian proses kerja, sebagai akibat dari kontak dengan substansi atau sumber energi yang melebihi batas kemampuan tubuh, alat, atau struktur.

Proyek konstruksi memang memiliki sifat yang unik, yaitu tempat kerjanya di ruang terbuka yang dipengaruhi cuaca, jangka waktu pekerjaan yang terbatas, dan juga menggunakan peralatan kerja menyebabkan proyek konstruksi menjadi salah satu sektor yang rawan kecelakaan. Menurut Kementrian Ketenagakerjaan (Kemnaker) di Berita Republika, kecelakaan kerja yang terjadi sepanjang tahun 2017 tercatat sebanyak 80.393 kasus.

Loss Causation Model adalah suatu teori penyebab kecelakaan oleh Frank E. Bird yang merupakan pengembangan dari teori domino kecelakaan. Berbeda dengan teori domino, pada model ini tahapan kecelakaan terdiri atas loss (kerugian akibat kecelakaan), insiden, penyebab langsung, penyebab dasar, serta kurangnya control dari pihak manajemen.

\section{Hari kerja hilang dan jam kerja total}

Hari kerja hilang menurut Occupation Safety and Health Administration (OSHA) ialah setiap hari kerja dimana seorang pekerja tidak dapat mengerjakan seluruh tugas rutinnya karena mengalami kecelakaan kerja atau sakit akibat pekerjaan. Hari kerja hilang ini dapat dibagi menjadi dua macam:

1. Jumlah hari tidak bekerja (days away from work) yaitu semua hari kerja dimana seorang pekerja tidak dapat mengerjakan setiap fungsi pekerjaannya karena kecelakaan kerja atau sakit

2. Jumlah hari kerja dengan aktifitas terbatas (days of restricted activities) yaitu semua hari kerja dimana akibat dimana akibat mengalami kecelakaan kerja atau sakit, pekerja dialihkan sementara ke pekerjaan lain atau pekerja tetap bekerja pada tempatnya tetapi tidak dapat mengerjakan secara normal seluruh tugasnya

Jam kerja total di suatu perusahaan adalah seluruh jam kerja yang secara nyata dilakukan seluruh pekerja. Termasuk didalamnya jam kerja lembur. Tidak termasuk didalamnya jam kerja selama cuti resmi dan selama sakit walaupun menerima upah. Bagi pejabat atau petugas yang melakukan kerja, setiap hari kerja dihitung tujuh jam. Jam kerja hilang adalah jumlah hari kerja hilang dikali tujuh jam.

\section{Waktu}

Kinerja waktu adalah membandingkan antara waktu yang telah direncanakan dan disepakati antara owner dengan kontraktor dengan waktu aktual penyelesaian proyek (actual work), bila presentasenya makin kecil maka kinerjanya makin baik (Dipuhusodo, 1996).

Pada pelaksanaan proyek konstruksi, bebarapa hal yang tidak diharapkan dan tidak diantisipasi dapat terjadi dan mempengaruhi waktu penyelesaian yang dibutuhkan. Suatu proyek terdiri dari kumpulan beberapa kegiatan pekerjaan yang saling berkaitan satu dengan yang lainnya. Keterlambatan penyelesaian suatu pekerjaan dapat terjadi akibat terlambat mulainya kegiatan tersebut atau perpanjangan durasi kegiatan tersebut. Keterlambatan suatu kegiatan akan dapat menjadikan keterlambatan proyek secara keseluruhan (Susanto, 2009).

\section{METODELOGI PENELITIAN}

\section{Populasi dan sampel}

Sasaran populasi pada penelitian ini adalah proyek konstruksi gedung bertingkat Indonesia 1 dan The Spring Residence. Sampel dalam penelitian ini adalah pekerja pada proyek tersebut. 


\section{Variabel penelitian}

Variabel yang digunakan dalam penelitian ini meliputi variable dependen dan independent. Variabel independen disimbolkan dengan X dan variabel dependen disimbolkan dengan Y. Variabel X dalam penelitian ini menyatakan faktor - faktor keselamatan dan kesehatan kerja dan tingkat kecelakaan kerja, sedangkan variabel Y menyatakan kinerja waktu. Penentuan kinerja waktu penyelesaian proyek dalam penelitian ini didapat dari persepsi rensponden terhadap kinerja waktu proyek antara progres kerja proyek aktual dengan rencana.

Tabel 1 Variabel Penelitian

\begin{tabular}{|c|c|}
\hline Keterangan & Sumber \\
\hline Buku panduan pelaksanaan K3 & Khrisna Mochtar, 2003 \\
\hline Pengetahuan terhadap kebijakan K3 perusahaan & Hidayat, M.T., 2011 \\
\hline Tanggung jawab semua pihak terhadap K3 & Hidayat, M.T., 2011 \\
\hline Peraturan K3 yang menjamin perusahaan kerja yang aman dan sehat & Hidayat, M.T., 2011 \\
\hline Prosedur tentang penggunaan perlengkapan keselamatan & Hidayat, M.T., 2011 \\
\hline Perusahaan memiliki prosedur penanganan kecelakaan & Hidayat, M.T., 2011 \\
\hline Ketersediaan APD dan alat pemadam kebakaran & Fitriani Hidayat, 2013 \\
\hline Pelatihan penggunaan perlengkapan keselamatan terhadap pekerja & Hidayat, M.T., 2011 \\
\hline Pemeriksaan kesehatan secara rutin kepada setiap pekerja & Hidayat, M.T., 2011 \\
\hline Penyimpanan catatan kesehatan pekerja & Hidayat, M.T., 2011 \\
\hline Promosi K3 melalui poster. billboard, spanduk/bulletin K3 & Hidayat, M.T., 2011 \\
\hline Melakukan komunikasi antar personil K3 dengan pekerja proyek & Hidayat, M.T., 2011 \\
\hline Mengadakan kerjasama dengan pihak rumah sakit & Hidayat, 2001 \\
\hline Menjalin hubungan yang erat dengan pihak asuransi & Asiyanto, 2005 \\
\hline Membuang material sisa/sampah & Asiyanto, 2005 \\
\hline Pencatatan dan pelaporan setiap insiden atau kecelakaan & Hidayat, M.T., 2011 \\
\hline Inspeksi harian pekerja dan daerah kerja oleh supervisor & Hidayat, M.T., 2011 \\
\hline Peningkatan dan perbaikan kinerja K3 & Hidayat, M.T., 2011 \\
\hline Jumlah pekerja yang cukup untuk menyelesaikan pekerjaan & Fitriani Hidayat, 2013 \\
\hline Safety meeting yang dilakukan secara berkala oleh setiap pekerja & Hidayat, M.T., 2011 \\
\hline Mengatur penempatan prasarana kerja, peralatan, dan bahan & Hidayat, 2001 \\
\hline
\end{tabular}

\section{Analisa deskriptif}

Data yang telah di tabulasi kemudian di analisis secara deskriptif yaitu dengan menghitung mean. Kemudian dari data rata-rata dapat diketahui dan diambil kesimpulan mengenai tingkat penerapan K3 yang berpengaruh terhadap kinerja waktu pada proyek $\mathrm{X}$ dan seberapa besar pengaruhnya terhadap kinerja waktu.

\section{Uji validitas}

Uji validitas menggunakan metode Pearson Product Momen, yaitu dengan mengkorelasikan skor butir pada kuisioner dengan skor totalnya. Item pertanyaan yang berkorelasi signifikan dengan skor total menunjukan bahwa item tersebut mampu memberikan dukungan dalam mengukur apa yang hendak kita ukur. Nilai koefisien korelasinya kemudian dibandingkan dengan nilai $r$ tabel dengan melihat jumlah sampel dan tingkat signifikansi 5\%. 


\section{Uji reliabilitas}

Uji Reliabilitas yang digunakan adalah metode Cronbach's Alpha dengan taraf signifikansi 5\%. Nilai Cronbach's Alpha menunjukkan nilai keandalan dari butir pertanyaan yang diuji. Nilai $\alpha$ kemudian dibandingkan dengan nilai $\mathrm{r}$ tabel untuk melihat apakah data reliabel.

\section{Uji normalitas}

Salah satu syarat untuk analisis korelasi dan regresi yaitu data berdistribusi normal. Uji normalitas yang dilakukan menggunakan ui Kolmogorov-Smirnov dengan menggunakan taraf signifikansi 0.05.

\section{Uji heterokesdastisitas}

Data yang baik tidak terjadi heteroskesdasitas. Uji heteroskesdasitas dilakukan dengan menggunakan grafik scatterplot antara Y prediksi pada sumbu x dengan residual (Y prediksi - Y) pada sumbu y. heteroskesdasitas tidak terjadi apabila grafik tidak menggambarkan pola tertentu (tidak jelas).

\section{Analisis korelasi}

Analisis korelasi dalam penelitian ini menggunakan analisis korelasi sederhana Pearson Product Moment. Analisis ini digunakan untuk mengukur kekuatan hubungan antara dua variabel. Semakin nilai korelasi yang didapat mendekati 1, maka semakin tinggi korelasi antara dua variabel tersebut. Nilai $r$ yang mendekati nol menyatakan bahwa korelasi yang terdapat antara dua variable sangatlah kecil. Ukuran yang digunakan untuk mengukur derajat hubungan (korelasi) linier disebut koefisien korelasi (correlation coefficient) yang dinyatakan dengan notasi " $\mathrm{r}$ " yang sering dikenal dengan nama "Koefisien Korelasi Pearson atau Product Moment Coefficient of Correlation".
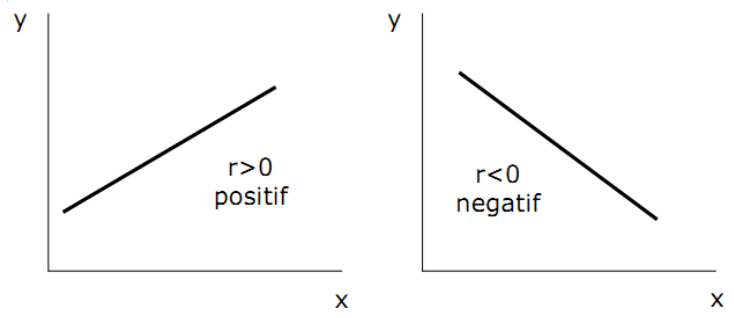

Gambar 1 Jenis Korelasi (Ghozali, 2013)

\section{PENGUMPULAN DAN ANALISIS DATA}

\section{Pengumpulan data}

Wawancara terstruktur dilakukan terhadap 42 responden secara acak berisi pertanyaan-pertanyaan sehingga diketahui bagaimana penerapan faktor-faktor K3 dan kinerja waktu pada proyek tersebut. Dari 42 wawancara terstruktur terhadap responden, 40 kuisioner dipakai untuk diolah lebih lanjut. Sedangkan 2 data lainnya tidak dipakai dikarenakan ketidaklengkapan data ataupun pengisian secara asal-asalan. Data-data yang didapat kemudian dikumpulkan dalam suatu tabel berupa tabulasi data. Data tersebut diolah menggunakan bantuan program software terapan SPSS versi 24 untuk menguji data sehingga didapat korelasi faktor penerapan K3 terhadap kinerja waktu yang paling dominan.

\section{Data umum responden}

Wawancara terstruktur dilakukan dengan menyebarkan kuisioner terhadap responden yaitu pekerja pada proyek konstruksi. Data umum dari responden dapat dilihat dalam tabel berikut: 
Tabel 2 Pengalaman Kerja

\begin{tabular}{|c|c|c|c|}
\hline Pengalaman Kerja & Frekuensi & $\%$ & $\%$ kumulatif \\
\hline $1-2$ & 7 & 17.5 & 17.5 \\
\hline $3-4$ & 9 & 22.5 & 40 \\
\hline $5-6$ & 4 & 10 & 50 \\
\hline $7-8$ & 6 & 15 & 65 \\
\hline $9-10$ & 5 & 12.5 & 77.5 \\
\hline$>10$ & 9 & 22.5 & 100 \\
\hline Total & 40 & & \\
\hline
\end{tabular}

Tabel 3 Pendidikan Responden

\begin{tabular}{|c|c|c|c|}
\hline Pendidikan & Frekuensi & $\%$ & $\%$ kumulatif \\
\hline SMP & 0 & 0 & 0 \\
\hline SMA & 8 & 20 & 20 \\
\hline SMK & 4 & 10 & 30 \\
\hline S1 & 14 & 35 & 65 \\
\hline S2 & 1 & 2.5 & 67.5 \\
\hline S3 & 0 & 0 & 67.5 \\
\hline D3 & 13 & 32.5 & 100 \\
\hline Total & 40 & & \\
\hline
\end{tabular}

\section{Hasil analisis deskriptif}

Analisis deskriptif dalam penelitian ini bertujuan untuk mengetahui gambaran secara umum dari penerapan Keselamatan dan Kesehatan Kerja (K3) dan kinerja waktu dari proyek konstruksi gedung bertingkat berdasarkan jawaban dari para responden. Analisis deskriptif ini dilakukan dengan melihat nilai mean (rata-rata) dari tiap variabel K3 yang ada.

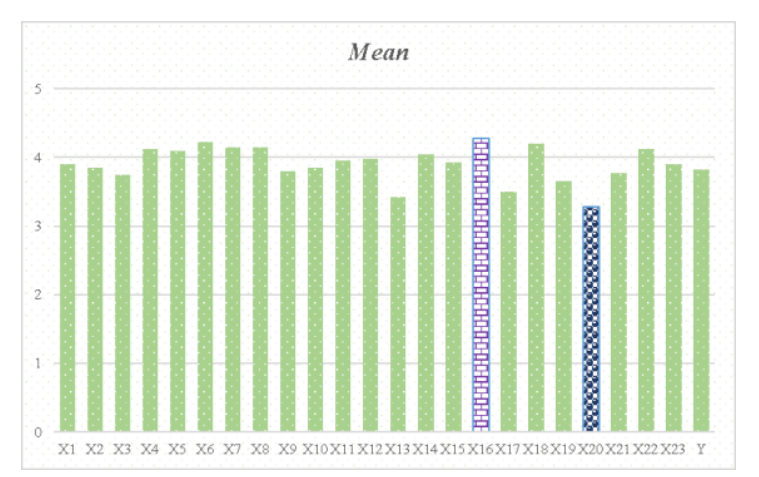

Gambar 2 Grafik Nilai Rata-Rata Penerapan K3 Proyek

Gambar 2 menunjukan nilai rata-rata dari tiap variabel x yaitu penerapan K3 dan y yaitu kinerja waktu proyek. Variabel y (kinerja waktu) memiliki nilai rata-rata yaitu 3.83 sehingga dapat diambil kesimpulan bahwa kinerja waktu pada proyek konstruksi tinggi.

Dari data dan grafik didapat bahwa nilai rata-rata tertinggi variabel x (penerapan K3) adalah pada variabel X16 yaitu menjalin hubungan yang erat dengan pihak asuransi dengan nilai 4.28. Nilai rata-rata terendah yaitu pada variabel X20 yaitu peningkatan dan perbaikan kinerja K3 dengan nilai 3.28. Maka dapat diambil kesimpulan bahwa secara keseluruhan penerapan K3 pada proyek telah dilakukan dengan cukup baik. 


\section{Hasil uji validitas}

Uji validitas data menggunakan bantuan program terapan dengan metode Pearson Product Momen, yaitu dengan mengkorelasikan skor butir pada kuisioner dengan skor totalnya.

Tabel 4 Contoh Hasil Uji Validitas

\begin{tabular}{|l|l|}
\hline & \multicolumn{1}{|c|}{ Total Score Pearson Correlation } \\
\hline X1 & 0.077 \\
\hline X2 & $.552^{* *}$ \\
\hline X4 & $.550^{* *}$ \\
\hline
\end{tabular}

Hasil uji validitas pada tabel 4 kemudian dibandingkan nilai $r$ nya dengan nilai $r$ tabel yaitu 0.312 . Hasil validitas menunjukkan bahwa 21 variabel $\mathrm{x}$ memiliki nilai $\mathrm{r}$ lebih besar dari nilai $\mathrm{r}$ tabel (0.312). 21 variabel tersebut yaitu X2, X3, X4, X5, X6, X7, X8, X9, X10, X11, X12, X13, X14, X15, X16, X17, X18, X19, X21, X22, X23. hal ini menunjukkan bahwa 21 variabel tersebut valid. Tingkat kecelakaan dan kinerja waktu memiliki nilai $\mathrm{r} 0.658$ dan0.751 lebih besar dari 0.312 sehingga valid. Variabel X1 dan X20 memiliki nilai $r$ yang lebih kecil dari nilai $r$ tabel (0.312) yaitu sebesar 0.077 dan 0.096 sehingga dinyatakan tidak valid. Kedua variabel kemudian dihapus dan dilakukan uji validitas ulang hingga semua variabel valid.

\section{Hasil uji reliabilitas}

Uji Reliabilitas penelitian menggunakan bantuan program terapan yaitu dengan metode Cronbach Alpha. Menurut Nunnally (1994), nilai Cronbach Alpha yang baik yaitu lebih besar dari 0.7 .

Tabel 5 Hasil Uji Reliabilitas

\begin{tabular}{|r|r|}
\hline \multicolumn{2}{|c|}{ Reliability Statistics } \\
\hline Cronbach's Alpha & N of Items \\
\hline .907 & 23 \\
\hline
\end{tabular}

Nilai Cronbach Alpha hasil analisis didapat 0.907 lebih besar dari nilai r tabel 0.312 sehingga berarti reliabel. Kemudian nilai Cronbach Alpha 0.907 juga lebih besar dari 0.7 yang berarti bahwa data memiliki nilai reliabilitas yang baik.

\section{Hasil uji normalitas}

Uji normalitas penelitian menggunakan uji Kolmogorov-Smirnov dengan menggunakan signifikansi 0.05. Data dianggap mempunyai distribusi normal (Ho diterima) apabila mempunyai nilai signifikansi lebih besar dari 0.05 . Hasil uji normalitas menunjukkan nilai Kolmogorov smirnov 0.084 dengan signifikansi 0.2 yang lebih besar dari 0.05 maka dapat diambil kesimpulan bahwa data berdistribusi normal.

Tabel 6 Hasil Uji Normalitas

\begin{tabular}{|c|c|c|}
\hline \multicolumn{3}{|c|}{ One-Sample Kolmogorov-Smirnov Test } \\
\hline & & $\begin{array}{l}\text { Unstandardized } \\
\text { Residual }\end{array}$ \\
\hline \multicolumn{2}{|l|}{$\mathrm{N}$} & 40 \\
\hline \multirow[t]{2}{*}{ Normal Parameters ${ }^{\mathrm{a}, \mathrm{b}}$} & Mean & .00 \\
\hline & Std. Deviation & .427 \\
\hline \multirow{3}{*}{ Most Extreme Differences } & Absolute & .084 \\
\hline & Positive & .079 \\
\hline & Negative & -.084 \\
\hline \multicolumn{2}{|l|}{ Test Statistic } & .084 \\
\hline \multicolumn{2}{|l|}{ Asymp. Sig. (2-tailed) } & $.200^{\mathrm{c}, \mathrm{d}}$ \\
\hline \multicolumn{3}{|l|}{ a. Test distribution is Normal. } \\
\hline \multicolumn{3}{|l|}{ b. Calculated from data. } \\
\hline \multicolumn{3}{|c|}{ c. Lilliefors Significance Correction. } \\
\hline \multicolumn{3}{|c|}{ d. This is a lower bound of the true significance. } \\
\hline
\end{tabular}




\section{Hasil uji heterokesdastisitas}

Kondisi data yang baik adalah data yang tidak terjadi heterokedastisitas. Uji heterokedastisitas dilakukan dengan melihat grafik keragaman data.

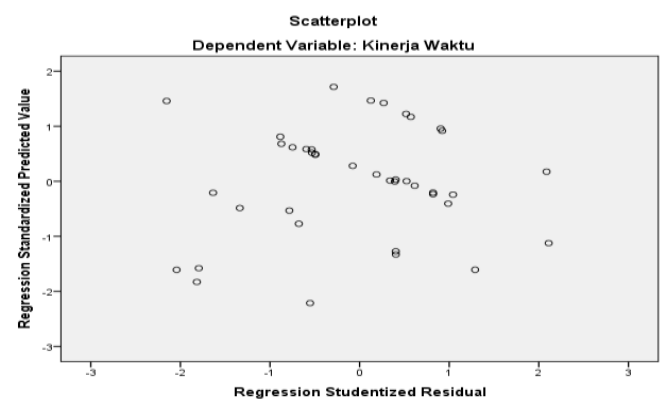

Gambar 3 Grafik Uji Heterokesdastisitas

Hasil uji heterokedastisitas ditunjukkan pada gambar 3 dimana grafik menunjukkan pola yang tidak jelas. Oleh karena itu dapat disimpulkan bahwa tidak terjadi heterokedastisitas.

\section{Hasil analisis korelasi}

Tabel 7 Variabel Yang Berkorelasi Signifikan Terhadap KinerjaWaktu

\begin{tabular}{|c|c|c|}
\hline Var & $\mathbf{r}$ & Keterangan \\
\hline $\mathbf{X 2 3}$ & 0.662 & Mengatur penempatan prasarana kerja, peralatan, dan bahan \\
\hline $\mathbf{X 1 7}$ & 0.511 & Membuang material sisa/sampah \\
\hline $\mathbf{X 1 0}$ & 0.494 & Pelatihan penggunaan perlengkapan keselamatan terhadap pekerja \\
\hline $\mathbf{X 3}$ & 0.481 & Tanggung jawab semua pihak terhadap K3 \\
\hline $\mathbf{X 1 9}$ & 0.468 & Inspeksi harian pekerja oleh supervisor \\
\hline $\mathbf{X 9}$ & 0.453 & Ketersediaan APD dan alat pemadam kebakaran \\
\hline $\mathbf{X 1 3}$ & 0.436 & Promosi K3 melalui poster, spanduk/ bulletin K3 \\
\hline $\mathbf{X 8}$ & 0.424 & Pemberian sanksi kepada pekerja yang tidak mentaati peraturan dan prosedur K3 \\
\hline $\mathbf{X 2}$ & 0.406 & Pengetahuan terhadap kebijakan K3 perusahaan pada semua pekerja \\
\hline $\mathbf{X 2 1}$ & 0.405 & Jumlah pekerja yang cukup untuk menyelesaikan pekerjaan \\
\hline $\mathbf{X} 7$ & 0.368 & Pemberian penghargaan kepada pekerja yang memiliki kinerja K3 yang baik \\
\hline $\mathbf{X 2 2}$ & 0.362 & Pelaksanaan safety meeting secara berkala \\
\hline $\mathbf{X 1 8}$ & 0.349 & Pencatatan dan pelaporan setiap insiden atau kecelakaan \\
\hline $\mathbf{X 1 4}$ & 0.347 & Mengadakan komunikasi antar personil K3 dengan pekerja proyek \\
\hline X6 & 0.335 & Perusahaan memiliki prosedur penanganan kecelakaan \\
\hline $\mathbf{X 1 1}$ & 0.323 & Pemeriksaan kesehatan secara rutin kepada setiap pekerja \\
\hline
\end{tabular}


Tabel 8 Variabel Yang Berkorelasi Tidak Signifikan Terhadap KinerjaWaktu

\begin{tabular}{|l|c|l|}
\hline Var & $\mathbf{r}$ & \multicolumn{1}{|c|}{ Keterangan } \\
\hline X12 & $\mathbf{0 . 1 4 0}$ & Penyimpanan catatan kesehatan pekerja \\
\hline $\mathbf{X 4}$ & $\mathbf{0 . 2 5 5}$ & Perusahaan memiliki peraturan K3 yang menjamin pekerjaan yang aman dan sehat \\
\hline $\mathbf{X 1 6}$ & $\mathbf{0 . 2 5 7}$ & Menjalin hubungan yang erat dengan pihak asuransi \\
\hline $\mathbf{X 1 5}$ & $\mathbf{0 . 2 6 5}$ & Mengadakan kerja sama dengan pihak rumah sakit \\
\hline
\end{tabular}

Hasil Analisis korelasi menunjukkan bahwa dari 21 variabel independen X (penerapan K3), terdapat 5 variabel independen yang tidak berkorelasi secara signifikan terhadap variabel dependen Y (kinerja waktu). Variabel X4, X5, $\mathrm{X} 12$, X15 dan X16 memiliki nilai $r$ yang lebih kecil dari nilai $r$ tabel $(0.312)$ sehingga korelasi dianggap tidak signifikan terhadap kinerja waktu.

Hasil analisis menunjukkan variabel penerapan K3 yang memiliki korelasi paling tinggi terhadap kinerja waktu yaitu X23 yaitu mengatur penempatan prasarana kerja, peralatan, dan bahan dengan nilai $\mathrm{r}$ sebesar 0.662 . Hasil menunjukan bahwa korelasi antara tingkat kecelakaan terhadap kinerja waktu memiliki hubungan korelasi yaitu sebesar 0.845. Hal ini membuktikan bahwa tingkat kecelakaan memiliki korelasi yang kuat terhadap kinerja waktu.

\section{PENUTUP}

\section{Kesimpulan}

1. Hasil analisis penerapan K3 pada tempat penelitian proyek konstruksi gedung bertingkat menunjukan nilai ratarata masing-masing penerapan (variabel X) memiliki nilai berkisar 3 (cukup) sampai 4 (baik). Maka dapat disimpulkan bahwa penerapan K3 pada proyek konstruksi dilaksanakan dengan cukup baik. Hal ini didukung dengan pengamatan di lapangan yaitu tersedianya APD lebih yang dapat dipinjamkan untuk para pekerja, posterposter K3 yang terpasang, safety meeting yang dilakukan secara berkala, dan petugas safety yang berkeliling mengawasi para pekerja.

2. Dari total 21 variabel independen penerapan K3, terdapat 16 variabel yang berkorelasi signifikan terhadap kinerja waktu. 5 variabel lainnya memiliki korelasi yang tidak signifikan terhadap kinerja waktu. Penerapan K3 yang memiliki hubungan paling kuat dengan kinerja waktu yaitu mengatur penempatan prasarana kerja, peralatan, dan bahan dengan nilai $\mathrm{r}$ 0.662. penempatan peralatan dan juga bahan yang sembarangan dapat menyebabkan terjadinya kecelakaan yang kemudian akan berpengaruh terhadap kinerja waktu. Variabel membuang material sisa/sampah memiliki nilai korelasi $\mathrm{r}$ sebesar 0.511 terhadap kinerja waktu. Ini berarti bahwa pembuangan material sisa/sampah memiliki korelasi yang kuat dengan kinerja waktu dimana material sisa/sampah yang berantakan seperti paku dapat menyebabkan terjadinya kecelakaan kerja.

3. Hasil uji korelasi menunjukkan bahwa tingkat kecelakaan memiliki korelasi yang signifikan terhadap kinerja waktu penyelesaian proyek konstruksi dengan nilai r 0.845. Maka dapat diambil kesimpulan bahwa kecelakaan yang terjadi memiliki hubungan yang kuat terhadap kinerja waktu penyelesaian proyek sehingga keselamatan dan kesehatan kerja harus lebih diperhatikan agar tingkat kecelakaan dapat dikurangi yang menyebabkan kinerja waktu penyelesaian proyek semakin baik sesuai rencana.

4. Rata-rata penerapan variabel penerapan K3 yang paling berpengaruh terhadap kinerja waktu yaitu variabel “mengatur penempatan prasarana kerja, peralatan, dan bahan" memiliki nilai 3.9. Hal ini menunjukkan bahwa pengaturan prasarana kerja, peralatan, dan bahan sudah dilakukan dengan baik namun dapat ditingkatkan lagi penerapan nya sehingga strategi yang dapat diambil yaitu dengan peningkatan pengawasan terhadap pekerja mengenai hal penempatan peralatan dan bahan yang terkadang masih berserakan. Variabel "Membuang material sisa/sampah" memiliki nilai rata-rata penerapan 3.5. Hal ini menunjukan bahwa pembuangan material sisa/sampah dilakukan dengan cukup baik, namun dapat ditingkatkan lagi dengan menyediakan tempat pembuangan sampah yang lebih memadai. 


\section{Saran}

1. Penerapan K3 pada proyek konstruksi harus lebih ditingkatkan lagi terutama terhadap variabel-variabel penerapan yang berhubungan signifikan terhadap kinerja waktu agar penyelesaian proyek dapat sesuai dengan rencana. Ada beberapa hal yang perlu diperbaiki yakni sampah yang berserakan pada tempat-tempat tertentu, dan kurangnya petugas safety yang melakukan pengawasan sehingga semua area dapat diawasi dengan baik.

2. Penelitian ini dapat dikembangkan lebih lanjut dengan meneliti bagaimana pengaruh penerapan K3 terhadap kinerja waktu pada jenis proyek konstruksi lainnya seperti pada jembatan, jalan layang, jalan tol, dan lain lain dengan dibantu dengan data-data tambahan dari proyek agar hasil penelitian menjadi lebih baik lagi yang kemudian dapat dilanjutkan dengan analisis regresi.

\section{DAFTAR PUSTAKA}

A.S. Moenir. Pendekatan Manusia dan Organisasi Terhadap Pembinaan Kepegawaian. Jakarta: Gunung Agung, 1983.

Bird Jr., Frank and Germain L. George. Practical Loss Control Leadership. Georgia: Loganville, 1990.

Choudhry, R.M., et.al. Journal of Safety Management in Construction : Based Practices in Hongkong. Hongkong : American Society of Civil Engineering, 2008.

Depnaker. Petunjuk Pelaksanaan Keselamatan dan Kesehatan Kerja. 2004.

Dipohusodo, Istimawan. Manajemen Proyek \& Konstruksi. Jogjakarta : Kanisius, 1996.

Ervianto, W. Manajemen Proyek Konstruksi Edisi Revisi. Yogyakarta: Andi, 2005.

Fang, D.P. Benchmarking Studies on Construction Safety Management in China. Journal of Construction Engineering and Management. American Society of Civil Engineering, 2004.

Faridi, A. S., \& El-Sayegh, S. M. Significant Factors Causing Delay In The UAE Construction Industry. Construction Management and Economics, 2006.

Gay, L.R dan Diehl, P.L. Research Methods for Business and Management. New York: MacMilan Publishing Company, 1992.

Hidayat, MT. Penerapan Keselamatan dan Kesehatan Kerja pada Proyek Konstruksi di Balikpapan. Skripsi. Universitas 17 Agustus 1945 Samarinda.

Hidayat, S. Jurnal Info Manpro: Pengaruh Penerapan K3 Terhadap Kualitas Hasil Kerja dan Kenyamanan Kerja pada Proyek Pembangunan Gedung di Probolinggo. Malang: ITN Malang, 2014.

Hinze, W. Construction Safety. New Jersey: Prentice Hall Inc, 1997.

Ghozali, Imam. Aplikasi Analisis Multivariate Dengan Program IBM SPSS 23. Semarang: Badan Penerbit Universitas Diponegoro, 2013.

International Labour Organization (ILO). Keselamatan dan Kesehatan Kerja di Indonesia. Manila, 2009.

Jack R Meredith, Cs.Project Management and Managerial Approach.. New York : John Wiley \& Sons,1989.

Kerzner, Harold. Project Management : A system Approach to Planning, Schedulling, and Controlling, John and Wiley.Inc. Ninth Edition. New Jersey,2006.

Mangkunegara, AP. Manajemen Sumber Daya Manusia. Cetakan Pertama. Bandung: PT. Remaja Rosdakarya, 2004.

Mondy, R. Wayne. Manajemen Sumber Daya Manusia. Jakarta: Erlangga, 2008.

Naga, D.S. Teori Sekor Pada Pengukuran Mental Edisi Kedua. Jakarta: PT. Nagarani Citrayasa,2013

Nurhayati. Manajemen Proyek. Graha ilmu, Jogjakarta: Graha Ilmu, 2010.

Ramli, S.Sistem Manajemen Keselamatan \& Kesehatan Kerja OHSAS 18001. Jakarta : Dian Rakyat, 2010.

Ridley, John. Ikhtisar Kesehatan \& Keselamatan Kerja Edisi Ketiga. Jakarta: Erlangga, 2008.

Sholihah, Q dan Wahyudi Kuncoro. Keselamatan Kesehatan Kerja : Konsep Perkembangan dan Implementasi Budaya Keselamatan. Jakarta: EGC, 2014.

Soeharto, Imam. Manajemen Proyek Dari Konseptual Sampai Operasional. Jakarta: Erlangga,1995.

Sugiyono. Metode Penelitian Kuantitatif, Kualitatif dan R\&D. Bandung: Alfabeta,2010.

Suma'mur .P.K. Keselamatan Kerja dan Pencegahan Kecelakaan. Jakarta : PT. Gunung Agung ,1989.

Susanto A.B. Reputation Driven Corporate Social Responsibility pendekatan strategic management dalam CSR. Jakarta: Erlangga,2009.

Tarwaka. Manajamen dan Implementasi K3 di Tempat Kerja. Surakarta: Harapan Perss, 2008. 